\begin{tabular}{|r|c|c|}
\hline Received: August 2018 & Accepted: September 2018 & Published: October 2018 \\
\hline \multicolumn{3}{|c|}{ Article DOI: $\underline{\text { http://dx.doi.org/10.24903/sj.v3i2.170 }}$} \\
\hline
\end{tabular}

\title{
Understanding CDA: Histories, Remembering, And Futures
}

\author{
Siti Rafiah. MH
}

Lancang Kuning University

srafiah297@gmail.com

\begin{abstract}
The purpose of writing this library research article is to understand what Critical Discourse Analysis is. The article starts with a discussion of the origin of Critical Discourse Analysis (CDA), then exploring interdisciplinary based on the theory proposed by Norman Fairclough, the last part of the article discussed the principles of CDA. The present article employ a descriptive qualitative approach from reputable references which is relevant to the topics.
\end{abstract}

Key words: Critical discourse analysis, origin of CDA, CDA frameworks 


\section{INTRODUCTION}

Discourse; Analysis; Discourse Analysis; and Critical Discourse Analysis are the focus to discuss in this article. These terms have many perspectives of meaning that need to be underlined and understand in a dynamic perspectives. The terms above switch a massive discussion and explained briefly in many previous studies, Van Dijk (1997) Cameron (2001); quite different in seeing discourse is a term. However they are quite similar with the definitions from Foucault (1972) says discourse refers to complex constellations of beliefs and actions that comprise social practice. Further, Foucault explains that Discourse analysis' term has come to be used with a wide range of meanings which cover up a wide range of activities. It is used to illustrate activities at the intersection of disciplines as diverse as sociolinguistics, psycholinguistics, philosophical linguistics and computational linguistics. Founded on some linguists may concentrate on determining the formal properties of a language, the discourse analyst is committed to an investigation of what that language is used for.

T.A. Van Dijk (1995) essentially perceives discourse analysis as ideology analysis, because according to him, "ideologies are typical, through not exclusively, expressed and reproduced in discourse and communication, including non-verbal semiotic messages, such as pictures, photograph, and movies" (p. 17). A. De Fina (2006), "Discourse Analysis involves the study of both text and context".

Related to discourse analysis, Fairclough is one of the scientists who has a specific research on discussing the analysis, particularly about Critical Discourse Analysis (CDA). In this case, Fairclough (1995a) defines CDA as discourse analysis which aims to systematically explore often opaque relationships of causality and determination between (a) discursive practices, events, and texts, and (b) wider social and cultural structures, relations and process; to investigate how such practices, events and texts arise out of and are ideologically shaped by relations of power and struggles over power, and to explore how the opacity of these relationships between discourse and society is itself a factor securing power and hegemony.

There are many discourse analysis studies, such us media discourse, music discourse, political discourse analysis, and critical discourse analysis, etc. But, in this article just focuses on critical discourse analysis. In additions, explain what are the origins of CDA, interdisciplinary, theory by Fairclough and the principles of CDA. 


\section{CRITICAL DISCOURSE ANALYSIS OVERVIEW}

\section{a. The origins of $C D A$}

Critical Discourse Analysis (CDA) is kind of discourse analytical research which the point is to learn social power abuse, domination, and inequality that formed, production, and faced by texts and talks in social and political context. The Philosophical and linguistic according which CDA is grounded are certain branches of social theory and earlier discourse analysis, text linguistics and interactional sociolinguistics. Habermas (1981) is frequently cited by CDA writers. His key contribution in the theory of communicative actions is the notion of validity claims, which according to him, are universally presupposed in all discourse. Validity claims can be challenged and defended in a communication situation that is free from coercion, is only based on rational argument, and permits access to all who are affected by the discourse.

Creeds of CDA has been finding in critical theory by Frankfurt School before Civil War II (Rasmussen, 1996). CDA focuses on language and discourse are called by 'critical linguistics' that appear (particularly in England and Australia) in the late 1970's (Fowler, Roger, Bob Hodge, 1979). The University of East Angliamused a new trend of analysis, as linguists and literary theorists were interested in linguistics choice in literature. Later on, they would focus on other texts of relevance in the public sphere, especially the mass media. This did not mean only a terminological change (i.e. from linguistic criticism to critical linguistics). The new label, which is sometimes taken as synonymous with CDA, implied a new attitude in academe: The scholar's commitment to social injustice.

The East Anglia School proposed Hallidayian linguistics for the analysis of news texts (R. and G. K. Hodge, 1973). Language as social semiotic, the three meta functions, and transitivity and modality became staples in this new discipline. Chomsky (1957) was also appropriate since one of its main concerns is describing the implications of syntactic transformations: Passivisation and nominalization have been the focal point of many a CDA work. CDA include pragmatics, conversation analysis, narrative analysis, rhetoric, sociolinguistics, ethnography, and media analysis. 


\section{b. Theory by Fairclough's}

Norman Fairclough (born in 1941) is an emeritus Professor of Linguistics at Lancaster University. He is one of the founders of Critical Discourse Analysis as applied to sociolinguistics. CDA include texts, talk, video, and practices. Fairclough's line of study is oriented discourse analysis (TODA), to distinguish it from philosophical enquires not involving the use of linguistics methodology, is specially anxious with the mutual effect of formally linguistic textual properties, sociolinguistic speech genres, and formally sociological practices. Fairclough has a theory that has been central to CDA over more than the past ten years. Critical Language Study $(1989$, p. 5) is his earlier work approach to language and discourse. It tells us about the objective of this approach as "a contribution to a general rising of consciousness of exploitative social relations, through focusing upon language" (1989, p. 4). The aim is further develops his approach so that it is now one of the most comprehensive frameworks of CDA (Chouliaraki, L. \&Fairclough, 1999). Here is brief of Fairclough's work in CDA.

For Chouliaraki, L. \&Fairclough (1999), CDA "bring social science and linguistics ... together within a single theoretical and analytical framework, setting up a dialogue between them" (p. 6). The linguistics theory refers to Systematic Functional Linguistics (SFL), which has been the foundation for Fairclough's analytical framework as it has been for other practitioners in CDA (H. \& Kress, 1979). His approach also draws upon a number of critical social theorists, for example, Foucault (i.e. a concept of orders of discourse), Gramsci (concept of hegemony), (Habermas, 1981)Habermas (i.e. the concept of colonization of discourses), etc.

\section{c. Interdisciplinary of Critical Discourse Analysis}

Norman Fairclough divided the framework of Critical Discourse Analysis to threepart of frameworks, namely:

\section{1) Text}

One of three-part model by Fairclough is text. It involves linguistic analysis in terms of vocabulary, grammar, semantics, the sound system, and cohesionorganization above the sentence level (Fairclough, 1995b). Linguistic analysis is 
applied to text's lexical-grammatical and semantic properties, two aspects that have a mutual impact on each other (pp. 57-58). Any sentence in a text is analyzable in terms of the articulation of these functions, which he has relabeled representations (perhaps carrying particular ideologies), relations (for example formal or informal, close or distant (Norman Fairclough, n.d.-a)), and identities (for instance, in term of what is highlighted - whether status and role aspects of identity, or individual and personality aspect of identity).

\section{2) Discourse Practice}

This dimension has two facet: institutional process (e.g. editorial procedures), and discourse processes (changes the text go through in production and consumption (Fairclough, 1995) For Fairclough, "discourse practice straddles the division between society and culture on the one hand, and discourse, language and text on the other" (p. 60). On the other hand, discourse processes can be explained through discussing a core concept in his approach: intertextuality.

Linguistic analysis at the discourse level that Fairclough calls "intertextual analysis" Norman Fairclough (1995b) which focuses on the borderline between text and discourse practice in the analytical framework. The Intertextual analysis is looking at the text from the perspective of discourse practice, searching the traces of the discourse practice in the text. (p. 16). N. Fairclough (1992) identifies two types of intertextuality, manifest intertextuality, and constitutive intertextuality. Norman Fairclough (1995) claims that intertextual properties of a text are realized "in its linguistic features" since it is assumed that text "may be linguistically heterogeneous". In spite of everything, Norman Fairclough (1995b) asserts that linguistic analysis is descriptive in nature, whereas interpretative analysis is more interpretative. Linguistics features of texts provide evidence which can be used in the intertextual analysis, and intertextual analysis is a particular sort of interpretation of that evidence... (p. 61).

\section{3) Sociocultural Practice}

Fairclough divided to three aspects of the sociocultural context of a communicative event: economic: economic (i.e. economy of the media), political (i.e. power and ideology of the media), and cultural (i.e. issues of values). According to 
him, one does not have to carry out an analysis at all levels but any level that might "be relevant to understanding the particular event" (p. 62).

However, Fairclough believes that reception studies (for instance, asking the audiences about their actual interpretations of text) could help discourse analysis in identifying meanings and effect of texts. Even so, he believes that text analysis should be the central element in media analysis provided that it is accompanied by analysis of text production and consumption (Norman Fairclough, 1995).

\section{d. Principles of CDA}

By way of concluding this section, principles of CDA, outlined by CDA practitioners (Norman Fairclough, 1995a; G. Kress, 1991; R. lan V. Hodge \& Kress, 1993; R. lan V. Hodge \& Kress, 1993a; Wodak, 1996) can be concluded as follows:

1. Language is a social practice through which the world is represented.

2. Discourse/language use as a form of social practice in itself not only represents and signifies other social practices but it also constitutes other social practices such as the exercise of power, domination, prejudice, resistance and so forth.

3. Texts acquire their meanings by the dialectical relationship between texts and the social subjects: writers and the readers, who always operate with various degrees of choice and access to texts and means of interpretation.

4. Linguistic features and structures are not arbitrary. They are purposeful whether or not the choices are conscious or unconscious.

5. Power relations are produced, exercised, and reproduced through discourse.

6. All speakers and writers operate from specific discursive practices originating in special interests and aims which involve inclusions and exclusions.

7. Discourse is historical in the sense that texts acquire their meanings by being situated in specific social, cultural and ideological contexts, and time and space.

8. CDA does not solely interpret texts but also explains them.

\section{CONCLUSION}

To sum up, as described above, CDA is a special approach in discourse analysis which focuses on the discursive conditions, components, and consequences of power abuse by dominant (elite) groups and institutions. It studies discourse and its functions in society and 
the ways society, and especially forms of equality, are expressed, repressed, represented, legitimated or reproduced in text and talk. Then again, CDA has its own aims, research programs, theoretical frameworks, and methods. It may highlight the relevance of power and dominance in studying text and talk, or of social arrangements and the social order in general in their relative to language use and communication. 


\section{BIBLIOGRAPHY}

A. De Fina, D. S. and M. B. (2006). Discourse and Identity. Cambridge: Cambridge: University Press.

Cameron, D. (2001). Working with Spoken Discourse. London: Sage.

Chomsky, N. (1957). Syntactic Structures. The Hague: Mouton.

Chouliaraki, L. \&Fairclough, N. (1999). Rethinking Critical Discourse Analysis. Edinburgh: Edinburgh University Press.

Fairclough, N. (n.d.-a). Critical Discourse Analysis: The Critical Study of Language. London: Longman.

Fairclough, N. (n.d.-b). Media Discourse. London: Edward Arnold.

Fairclough, N. (1992). Discourse and Social Change. Cambridge: Polity Press.

Foucault, M. (1972). The Archaeology of Knowledge (t. (A.M. Sheridan Smith, Trans.). New York: Pantheon Books.

Fowler, Roger, Bob Hodge, G. K. and T. T. (1979). Language and Control. London: Routledge.

Habermas, J. (1981). Theory of communicative action, Volume One: Reason and the rationalization of society (book). Boston, Mass: Beacon Press.

Hodge, R. and G. K. (1973). Language as Ideology. London and N.Y: Routledge\&Kegan Paul.

Hodge, R. lan V., \& Kress, G. R. (1993). Language as Ideology. Routledge.

Kress, G. (1991). Critical Discourse Analyze. Annual Review of Applied Linguistics (Vol.

11). New York: Cambridge University Press.

Kress, H. \&. (1979). No Title.

Rasmussen, D. M. (1996). The Handbook of Critical Theory. Oxford: Blackwell.

Van Dijk, T. A. (1995). Discourse Analysis as Ideology Analysis. In Language and Peace (In Christi, pp. 17-33). Dartmouth: Aldershot.

Van Dijk, T. A. (1997). "Discourse as Interaction in Society." In Teun A. van Dijk (Ed.), Discourse as Social Interaction (pp. 1-37). London: Sage.

Wodak, R. (1996). Disorders of Discourse. Longman. 